\title{
XXIII. On the Stream Works of Pentowan.
}

\section{By EDWARD SMITH, Esq.}

[Read June 3rd, 1814.]

W HEN, a little time back on a mining excursion in the district of St. Austle, my avocation for the first time called me to visit a stream-work in that neighbourhood, I was so struck with what I saw, that I employed a second day from morning to evening in a most scrupulous examination of one of the works, from a wish of communicating my observations to the Geological Society.

The works that I visited are called the upper and lower Pentowan Stream Works, and are situated on the river which flows from Hensbarrow Hill by St. Austle, and enters the sea about three miles and a half south of that town, and at about the same distance north of Chappel Point, after a course of somewhat more than eight miles. I calculate the elevation of Hensbarrow Hill at 900 or 1000 feet above the sea; from thence to St. Austle the descent of the ground being very rapid the river is precipitated over many considerable rocks, and during the rainy season may be considered as a succession of cascades. In the dry season there is but little water, but after sudden rains the rise is both rapid and dangerous. Small rounded pebbles are found all the way in this part of its bed. From St. Austle to the sea the descent of the land is very gentle, and the hills running north and south on each side of the river 
Mr. Sмiтн on the Stream Works of Pentowan.

seem to direct its course. In some places these approach very near together, in others they widen, and leave a greater expanse of plain. The whole of these levels from within half a mile of St. Austle to the sea having been found rich in deposits of tin, have at various times been turned over, and great quantities of ore have thus been obtained : they are all at this time enclosed and cultivated. At the mouth of the river the shore is flat on both sides to some distance; at half a mile to the east begin the high cliffs that extend to Black Bear point.

The Upper Pentowan work lies about one mile north of the beginning of the sea-beach, and about one mile and a quarter north of the sea, the valley being there about half a mile wide.

The following is the section of the Strata which I observed in the Upper Pentowan Stream Work.

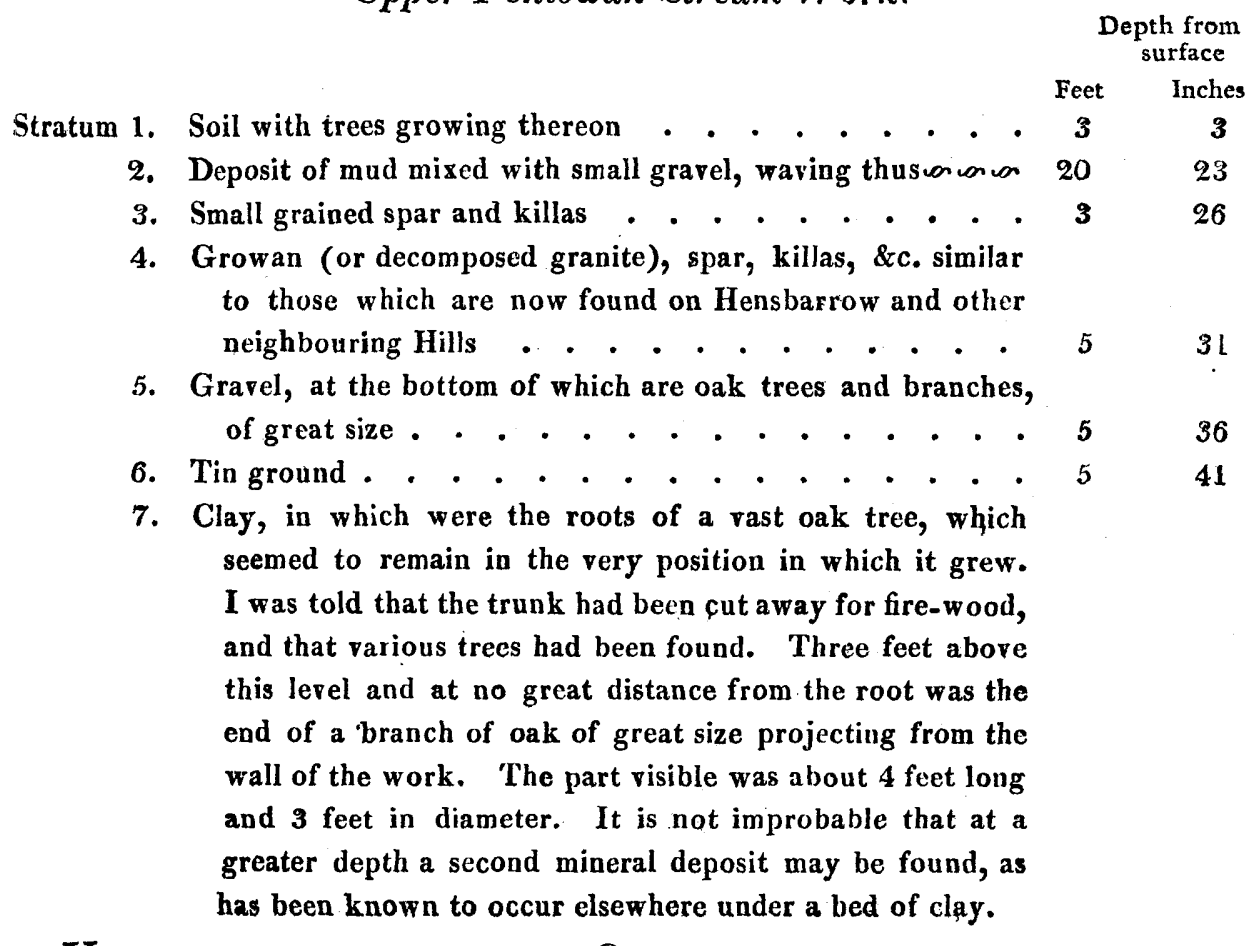


The lower Pentowan work lies three quarters of a mile south of the upper, and about half a mile north of the sea. The plain is more contracted here than at the upper work, and the river flows immediately west of the excavation, and nearly on a level with the upper part of it. The excavation measures from north to south about 400 feet, from east to west about 250, and is $54 \frac{x}{2}$ feet deep. In form it resembles an amphitheatre, being cut into deep stopes (as the miners term them) by which their work is upheld. The miner's object is to come at a deposit of tin five feet thick at the bottom of the pit, and as he works forward he throws behind him the waste matter. Water is conveyed from the river by a wooden trough into an insulated mass of the lower stratum, in which the tin is washed.

The following is the Section of the Strata at the Lower Work.

Stratum 1. Soil with trees growing in great luxuriance, some vory old, and gravel towards the bottom . . . . . .

\section{Depth from surface \\ Feet. Inches}

$3 \quad 3$

2. Fine peat. At the bottom are roots of trees, fallen trunks with iry attached to them, and sticks impregnated with salt. In this stratum also are found sea laver and

3. Sez mud, which when dry resembles fine grey sand. At the top are masses of leaves compressed flat, whose characters are still to be distinguished. Under the leaves are cockle shells, well preserved. These as the stratum deepens become more decayed. At 4 feet from the bottom of this stratum, and at 31 feet from the surface have been found many bones of animals, viz. the horns of two deer, very large and of equal size; two human. skults, one belanging to a child, the grinders not having yet shot through the jaw; the shoulder and thigh bone of some large animal; and the vertebræ of some smaller animals. At the bottom is a bed of very small shells in great abundance, 1 foot thick, and then a thin layer of small shells in a very decayed state . . . . . . 
Mr. Smith on the Stream Works of Pentowan.

\begin{tabular}{|c|c|c|c|c|}
\hline & & & & $\begin{array}{l}\text { th from } \\
\text { Ifface }\end{array}$ \\
\hline & & & Feet & Inches \\
\hline Stratum & 4. & Sea mud, with large oyster shells and cockles . . . . & 4 & 39 \\
\hline & 5. & Vegetable substances, with flat compressed leaves, and a & & \\
\hline & & few rotten shells $\quad . \quad . \quad . \quad . \quad . \quad . \quad . \quad . \quad . \quad . \quad .$. & $6 \frac{\pi}{2}$ & $45 \frac{1}{2}$ \\
\hline & 6. & $\begin{array}{l}\text { Vegetable substances, without shells; containing rushes, } \\
\text { fallen trees, flat compressed leaves, roots covered with } \\
\text { moss and compressed to an oval form, wings of coleop- }\end{array}$ & & \\
\hline & & terous insects . . . . . . . . . . . . . & 1 & $46 \frac{1}{2}$ \\
\hline & & $\begin{array}{l}\text { The trees in } 2,5 \text {, and } 6 \text {, are so numerous, that the miners } \\
\text { collect from them great stacks of fire-wood. }\end{array}$ & & \\
\hline & 7. & $\begin{array}{l}\text { At the top are found moss, sticks, hazle nuts. Beneath } \\
\text { are small stones of killas, growan, and other pebbles, } \\
\text { which are known by the miners to have belonged to the }\end{array}$ & & \\
\hline & & neighbouring hills, so far distant as Hensbarrow . . & 3 & $49 \frac{1}{2}$ \\
\hline & 8. & Rough tin ground, containing the lighter and poorer stones & 2 & $51 \frac{1}{2}$ \\
\hline & 9. & $\begin{array}{l}\text { Rough tin ground, containing rich tin stones, some of great } \\
\text { size and weight. Mixed with these are rounded pebbles } \\
\text { of quartz, and other stones, and a yellow ferruginous }\end{array}$ & & \\
\hline
\end{tabular}

10. Solid killas rock, on which all the preceding alluvia were deposited: The level of this does not differ much from that of low water mark.

In addition to these observations I have not many remarks to offer. The lower work is much richer in metallic produce than the upper, owing probably to the valley being narrower at the former place, which confined the mineral matter within a smaller space, and prevented it from being dispersed in the plain. The stones at the upper work were much the largest, as might be expected from its greater proximity to the hills. Among the tinstones of both works are found such as agree with the ores of particular lodes, that traverse the several hills all the way up to Hensbarrow hill, and the old miners had themselves made these distinctions, and rendered them perfectly clear to me. Thus, I think, I may venture to say, that the tin stones have been washed down from the neighbouring hills into the Pentowan valley. 
Mr. SмIтн on the Stream Works of Pentowan.

The chief difference to be observed in the strata of the two Pentowan Stream Works, is the want of marine matter in those of the upper. In the lower Stream Work I have described the killas rock, upon which are deposited 5 feet of tin ground, $10 \frac{1}{2}$ feet of vegetable matter, 24 feet of sea mud, and 3 feet of soil, on a level with which flows the river $54 \frac{1}{2}$ feet above the solid rock.

The following notice and sections bave also been transmitted to the Society.

British antiquities (celts, spear's heads, \&c.) have been discovered in the Stream Works at the depth of 20,30, and 40 feet, from whence it appears probable that the greatest part of the accumulation of soil has taken place at a comparatively modern period.

An accurate representation and description of the Stream Work at Porth in the parish of St. Blazey, of this county, have been presented to the public by Philip Rashleigh, Esq. in the second part of his Description of British Minerals, published in the year 1802.

Section of the Pentoroan Stream Work in 1807.

No. 1. Micaceous sandy clay, interspersed with stones and gravel .. . Feet

2. Peat, intermixed with roots and leaves . . . . . . . . 7

3. Sand, in which are found branches and trunks of trees ...$\quad$. 8

4. Finer sand with shells, in which bones, horns, \&c. are found .. 12

N. B. The horns are chiefly those of cattle and stags; a joint of the vertebra of a zohale, and a human skull were likewise found in this stratum, the former is now in the possession of the Rev. John Rogers, of Mawnan, in this county.

5. Coarse gravel

6. Closer sand mixed with clay, with decayed leaves, almost forming peat towards the bottom . . . . . . . . . . . . . . 12

7. Loose stones and gravel .

8. Tin Ground. 
Mr. Smitu on the Stream Works of Pentowan.

\section{Carnon Stream Work, 1807.}

Strata.

No. 1. Mud and sand . . . . . . . . . . . . . . .

2. Granite gravel intermixed with small pieces resembling charcoal; and a few shells . . . . . . . . . . . . 4 -

3. Fine gravel, mud and shells . . . . . . . . . . 12

About this depth are several irregular strata of oysters, about 4 or 5 feet in thickness, extending irregularly to within 4 or 5 feet of the tin ground.

4. Closer mud intermixed with shells . . . . . . . . .

In this stratum have been found several branches and trunks of trees, some of which had erident marks of being cut with an axe or other sharp instrument. Horns and bones of stags, likewise human skulls.

5. Tin Ground, varying in depth from 1 to 6 feet.

\section{Tregoney Stream Work, 1807.}

Strata.

No. 1. Granite gravel with layers of mud . . . . . . . . . 116

2. Black mud with a few shells . . . . . . . . . . . 15 -

N.B. In this stratum were found a cow's horn, 3 inches $\frac{3}{4}$ diameter, and 1 foot 1 inch in circumference; and several stags horns.

3. Tin Ground; average depth 2 feet. 